\title{
Assessment of the Effect of Farmers-Herdsmen Conflicts on National Integration in Nigeria
}

\author{
Aliyu, M. Kolawole, PhD \\ Ikedinma, Hope Amoge, PhD \\ Department of Political Science \\ Obafemi Awolowo University \\ Ile-Ife, Nigeria \\ Akinwande, Adeyoola Eunice \\ Department of Social Studies \\ Osun State College of Education \\ Ilesa, Osun State \\ Nigeria
}

\begin{abstract}
This study examined incidents of farmers-herdsmen conflicts, its causes and effects on national integration in Nigeria with the view to providing information on the intricacies of the conflicts in the country. The study employed case study research design to interrogate into the phenomenon of farmers-herdsmen conflicts and used secondary data such as books, research articles, newspapers and government publications in Nigeria. The data was content analyzed. The study found that farmers-herdsmen conflicts are not caused by a single reason but are propelled by multi-causal factors, such as limited resources in the face of greater need, reprisal attack, and shortage of land as well as climate change among others. The study also found that farmers-herdsmen conflicts have disintegrative effect on the country. The study concluded that farmers-herdsmen conflicts are inimical to the unity of the country and therefore recommended that visibility study should be carried out in consultation with state governments to ascertain the establishment of suitable cattle ranching reserves for herdsmen, restoration of earlier symbiosis relationship between herdsmen and farmers, and that Nigeria's porous borders be well monitored.
\end{abstract}

Keywords: conflict, farmers, herdsmen, farmers - herdsmen conflict, national integration

\section{Introduction}

There have been several cases of farmers-herdsmen conflicts across various states and locations in Nigeria. These conflicts have now become so threatening on the country's national integration, such that the hitherto peaceful relationship between farmers and herdsmen across various parts of Nigeria is degenerating to a carnage level, leading to loss of lives and properties. Attempts by the federal government to curb the incessant farmersherdsmen appear to be futile. According to Mwanfupe (2015), farmers-herdsmen conflicts are equally prevalent in Cameroon, Tanzania, Sudan and Kenya. Narrating the incidence of the conflicts in Tanzania, Mwanfupe (2015:34) notes that:

Policy deficiencies and contradictions on land tenure, inadequate capacity of the local institutions in settling such conflicts, violent nature of approach used to resolve and manage the conflicts - using police, corruption and politics of the belly, lack of coordination in settling the herdsmen and the villages lacking in land use plan.

He further concludes that, "unless security of tenure on land used by smallholders (both farmers and herdsmen) is restored, the conflicts between them will continue" (Mwanfupe, 2015:45). Mwanfupe equally recounts that a similar occurrence of farmers-herdsmen conflicts is witnessed in South West Burkina Faso which made state to suggest government roles in the management of the conflicts. It was suggested that state should engage in mediatory role between the conflicting parties so as to resolve the conflicts. Furthermore, they should employ political frameworks such as right policy formulation on habitats and budget allocation, so as to cater for the land and amenities needs of both rural and urban settlements. 
In Nigeria, however, Nzeh (2015) asserts that before the present farmers-herdsmen conflict assumed a dangerous dimension; the relationship between them had been a cordial and symbiotic one. He further posits that, upon herdsmen entry into Nigeria via the Nigeria/Cameroon border in search of pasture, the herdsmen settled in Borno/Adamawa where they found pasture and they had a peaceful symbiotic relationship with the farmers which was beneficial to both groups. He further asserted that the sufficiency of land for both farmers and herdsmen, given the subsistence nature of farming and the few numbers of cows that the herdsmen breed then, made them to co-exist peacefully, void of unhealthy competition over scarce resources. This same cordiality had usually played out between farmers and herdsmen in Nigeria until recently (Goke, 2018: 22).

However, conflicts between farmers and herdsmen emanated as a result of the increase in population of both the farmers and the herdsmen. This was sequel to the increase in the need for more farmland. Other causes of the conflict include: change in climate condition leading to draught and dessert encroachment; improvement in technology that brought about irrigation; the need to cultivate and produce more of the cash crops newly introduced. Conflict between farmers and herdsmen is reinforced by the farmers' habit of extending the boundary of their farms to livestock route and the herdsmen's habit of allowing cattle to veer into the farmers' farm to eat their plants and drop their dung either on the farm or on the pedestal route (Moritz, 2003). The farmers-herdsmen conflict in Riyom Plateau State; Agatu in Benue State, Nimbo in Enugu State and the alleged kidnapping of Chief Olu Falae (who is a farmer), by suspected herdsmen in Ondo State, is a new twist to the incidents of farmersherdsmen conflicts which affirm the fact that farmers-herdsmen conflict is assuming a national integration threatening dimension in Nigeria (Oyeyipo, James \& Sanda, 2015). Also, the recent farmers-herdsmen attacks in Oke-Ogun area of Oyo State, pose threat to the peaceful co-existence of the different ethnic nationalities in Nigeria.

The intractable nature of the conflict has prompted many studies by different researchers. Most of these studies note that the conflict is caused by population explosion, climate change, trampling of farmers' farms, rapping of female farmers, encroachment of livestock routes, and muddling of water ponds of communities by the herds. The findings of these studies revealed loss of human lives and cattle, displacement of farmers and/or herdsmen and reduction in farm produce as some of the general effects of the conflicts in Nigeria (Abbass, 2012; Audu, 2013; Nformi, et al., 2014; Ofem \& Bassey, 2014; Ezeh, 2015; Doyin, 2017 and Akorede, 2018). Farmers-herdsmen conflicts have gone beyond being a threat to individual lives but have now attained a national integration threatening dimension. In view of this, this study examines the incidents, causes and effects of the conflicts on national integration in Nigeria, especially between 2011 and 2018; when the issue of farmers-herdsmen conflicts have assumed 'integration threatening" dimension. This notwithstanding, references are made to earlier occurrences of such conflicts in Nigeria.

\section{Conceptualizations}

Conflict in this context connotes clash or disagreement between two or more groups who have incompatible differences. It is a situation where two or more parties pursue similar goals but believe that such goals are achievable by just one of them and employ every resource within their disposal to hinder the other party from attaining such goal. According to Maltosa (1999), conflict often expresses itself in the form of violence, and once it assumes this character, it becomes undesirable and counter-productive. Conflict can lead to mutual satisfaction and growth, and can produce hostilities. Galtung (1996) complemented the above position by arguing that conflicts have both life-affirming and life-destroying aspects. Similarly, Bloomfield, Ghai, and Reilly (2003) opine that conflict itself is not necessarily a negative process. It is one of the most powerfully positive factors for change in a society. Thus, conflicts can be harmful or harmless to humankind (Adeleke, 2018:18). It is the former, that is, harmful conflict which plagued Nigeria, via the farmers - herdsmen conflict which is the focus of this study.

For the purpose of this study, farmers mean only those who cultivate the land for plant produce. Most of these people are indigenous members of the community where they reside. In Nigeria, they are found in almost all the rural settings and cultivate at a subsistent level. Herdsmen, on the other hand, are people who rear livestock and mostly of the Fulani extraction. The particular group in this study is the transhumant category and not the sedentary type. This is because, the sedentary ones have little record of clashes with their host communities compared to the transhumant category which grazes livestock and shifts from one location to another where they can get feeds for their animals. 
Farmers-herdsmen conflict is basically the verbal and lethal confrontations that farmers usually have with the herdsmen as a result of their competition over the available resources of grazing farmland on one hand and drinking or use of water for irrigation on the other hand. National Integration is conceived as the feeling of unity and togetherness, which every Nigerian should have, to uphold the oneness of Nigeria. According to Oyedotun (2017), national integration is a process leading to political cohesion and sentiments of loyalty towards central political institutions. Maurice Duverger in Ojo (2009) defines national integration as the process of unifying a society which tends to make its harmonious city, based upon an order its members regard as equitably harmonious. Karl Deutsch et al. in Ojo (2009) views national integration as "the attainment, within a territory of a sense of community and of institutions and practices strong enough and widespread enough to assure, for a long time dependable expectations of peaceful community." From the foregoing definitions, it could be observed that national integration covers a vast range of human relationships and attitudes - the integration of diverse cultural loyalties and the development of a sense of nationality; and the integration of the citizens into a common political process.

\section{Theoretical Framework}

This study employed frustration-aggression theory as espoused by John Dollard in 1939 and expanded by Miller (1941) cited in Faleti (2015) to explain farmers-herdsmen clashes. This theory contends that the reason for the display of aggression by people is the feeling of not being able to completely get what they actually deserve. In other words, when what people get is lower than their expectations, they result to conflict. Faleti (2015) remarks that the difference between "expected need" and "actual need" that propelled some conflicts. He further posits that where expectation does not meet attainment, there is a high likelihood for the aggrieved party to confront anybody they feel is responsible for their inability to attain their desires. Frustration-aggression theory conceives conflict as the outcome of frustration of an individual or group from being unable to attain their legitimate desire. This theory has some major propositions which when explored are capable of explaining farmers-herdsmen conflicts in Nigeria. The first as espoused by Dollard et.al. (1939) posits that "the occurrence of aggressive behavior always presupposes the existence of frustration and, that the existence of frustration always leads to some form of aggression". This explanation of aggression as the only consequence of frustration was criticized. As a result of this criticism, Miller (1941) rephrased the second part of the theory which states that "frustration produces instigations to a number of different types of responses". Miller's intervention posits or entails that, there are several repercussions of frustration, one of which is aggression, unlike the original version, which posited just one outcome of frustration, which is aggression. However, Miller's reformulation sticks to the position that all aggressions are caused by frustration.

From another angle, the theory posits that frustration could be additive or accumulative. That is, minor frustration could lead to greater aggression than expected. They argue that, it is as a result of the accumulation or addition of the present, with the previous residual frustration, that the aggression became high. The argument asserts that not all frustrations lead to overt aggression. This means that there are some frustrations whose reactions are not immediate but are postponed to the instigation of a further frustration. These theorists also assert that the presence of some inhibitions to the overt demonstration of aggression in the form of repercussive punishment to a loved one is the course of demonstrating such aggression. When such punishment is greater than the goal they initially aspired, they tend to vent their aggression in a milder way by demonstrating overt anger or redirecting their aggression.

This takes us to their next major postulation which states that "a particular frustration instigates aggression primarily against the source of frustration but also instigates aggression against targets that are, to some degree, related to that source". It means that the targets of aggression are not always the sources of the frustration (Akorede, 2018:14). Aggressions are sometimes redirected at people or things that are related to the major target, where such targets cannot be reached (Dollard, et.al. 1939). This theory can be captured in the behaviors of belligerent parties involved in the conflict of farmers and herdsmen. Sometimes, a party suddenly lunch assault on the other without any harm previously done by them. Such action could be situated within the delay or transfer of aggression theory. It could be reprisals of a frustration meted on them by those they feel are connected with the present group they are attacking.

Frustration-aggression theory explains the farmers-herdsmen conflict in the sense that, they both feel they are legitimately entitled to pasture land and water due to the nature of their occupation. 
The farmers feel that, by virtue of being the indigenous owners of the land, there should be no further reduction on the limited available land which is not commensurately owned with their given demographic explosion. They feel that Fulani's encroachment on their land is a hindrance to attaining their full farming potential, since they have large families that cultivate large expanse of land. The Fulani on the other hand feel that the farmers are problems to them in accessing pasture land and water, thereby mal-nourishing their cattle and reducing their market value by making them less attractive. The Fulani's major preoccupation is to have a large herd of cattle, and any hindrance to achieving such a goal is confronted with very strong aggression and attack.

\section{History of Fulani Herdsmen and Farmers Clashes in Nigeria}

Fulani herdsmen and farmers clashes are dated to 2012. Before then, there has been peaceful relationship among farmers and herdsmen across the states in Nigeria, except few cases of minor misunderstandings that did not claim life (Nzeh, 2015 and Doyin, 2017). According to Omawumi (2016), the current feud started because of farming, grazing land and water. The farmers accused the herdsmen of damaging their crops by failing to control their animals while the herdsmen equally claimed that the farming communities steal their cattle (Adeleke, 2018). In September 30, 2012, one Mr. Benjamin Chegue, a Director of Personnel Management was killed in Isoko North Local Government Area of Delta state and since then, the spate of killings linked to farmers-herdsmen clashes had continued across the states in Nigeria as compiled below:

\begin{tabular}{|c|c|c|}
\hline Date & Places & Causalities \\
\hline April 5, 2014 & Galadima village & $\begin{array}{l}\text { Community leaders and over } 200 \text { residents were killed with } \\
\text { unknown number seriously injured. }\end{array}$ \\
\hline February18, 2016 & $\begin{array}{l}\text { Okokolo village in Agatu } \\
\text { Local Govt. Area of Benue } \\
\text { State }\end{array}$ & Five persons killed and properties destroyed. \\
\hline March 5,2016 & $\begin{array}{l}\text { Alla, Akwu, Adagbo, } \\
\text { Okokolo, Odugbento, } \\
\text { Ogbaulu, Egba and Obaganji } \\
\text { communities in Agatu Local } \\
\text { Govt. }\end{array}$ & $\begin{array}{l}\text { About } 500 \text { persons killed, many people injured and } \\
\text { properties worth millions of naira destroyed. }\end{array}$ \\
\hline April 12, 2017 & $\begin{array}{l}\text { Two villages in Gashaka } \\
\text { Local Govt. Area of Taraba } \\
\text { state }\end{array}$ & About 15 persons were killed. \\
\hline April 19, 2017 & $\begin{array}{l}25 \text { Local Govt. blocked Benin } \\
\text { - Asaba Highway }\end{array}$ & $\begin{array}{l}\text { In protest of earlier killings of about } 23 \text { persons by Fulani } \\
\text { herdsmen. }\end{array}$ \\
\hline April 21, 2017 & $\begin{array}{l}\text { Lagun village in Iyana Offa, } \\
\text { Atagba, Lapata and } \\
\text { sorroundings in Lagelu Local } \\
\text { Govt. Area of Oyo state }\end{array}$ & $\begin{array}{l}\text { A night guard killed, villages ransacked at night and } \\
\text { valuables carted away. }\end{array}$ \\
\hline April 25,2018 & $\begin{array}{l}\text { Seven villages in Nimbo in } \\
\text { Uzo - Uwani Local Govt. } \\
\text { Area of Enugu state }\end{array}$ & About 40 persons killed and properties destroyed. \\
\hline June 16,2018 & $\begin{array}{l}\text { Ossisa community in Ndokwa } \\
\text { East Local Govt. Area of } \\
\text { Delta state }\end{array}$ & A 45 year old farmer was shot dead. \\
\hline June 20,2018 & $\begin{array}{l}\text { Ugondo, Turan and Gabo - } \\
\text { Nenzev in Logo Local Govt. } \\
\text { Area of Benue state }\end{array}$ & 59 persons were killed \\
\hline
\end{tabular}

Source: Compiled by the authors from secondary sources

\section{Empirical incidents of Farmers-Herdsmen Conflicts in Nigeria}

This segment examines some incidents of farmers-herdsmen conflicts in the country. At least, a case of farmersherdsmen conflict in a state in each of the six geo-political zones in the country is examined.

\section{Experience from the South West}

The governor of Ekiti State, Governor Ayodele Fayose declared war against the herdsmen, following alleged killing of two people in the State. 
The governors' threat was initially provoked by an earlier attack reportedly carried out by herdsmen on the 20 May, 2016, at Oke Ako, where five people were allegedly killed. In September 21, 2015, herdsmen numbering over 20 were equally reported to have abducted a former Secretary to the Government of the Federation (SGF) and chieftain of Afenifere, Chief Samuel Oluyemisi Falae on his $77^{\text {th }}$ birthday after invading his farm in Ilado Village, Akure North Area of Ondo State (Oyedotun, 2017). Less than two hours after the incident, the kidnappers were said to have demanded N100m ransom but after about 96 hours, Falae, who was also a former Finance Minister, was said to have regained his freedom after he was reportedly rescued by a team of security operatives led by the former Inspector General of Police, Solomon Arase (Doyin, 2017). Following Falae's abduction, the Afenifere cultural group called for the expulsion of the herdsmen from the South-West, if they would continue to jeopardize the peace in the region (Thisday, 2016). On the same day, farmers in Lagun, Iyana Offa, Atagba, Lapata and the surrounding communities in Lagelu Local government area of Oyo State reported that they were attacked by herdsmen who also stole valuables from them (Punch, 2016). Saki, Ago-Are, Oje- Owode areas of Oyo state have been severally reported of having severe encounters of farmers and herdsmen (Vanguard, 2016). In each of the conflict, lives and properties were reported to have been lost and villagers displaced (Adeleke, 2018).

\section{Menace of the Conflict in the North-Central}

In March 2016, the people of Agatu Local Government of Benue state, comprising of communities such as Aila, Akwu, Adagbo, Okokolo, Ugboju, Odugbeho, Ogbaulu, Egba and Obagji, witnessed herdsmen attack that resulted in the death of over 300 people. Houses, schools, health centres and worship centres were razed down (The nation, 2016). The cause of the carnage was reported to be a reprisal attack by the Fulani over their 10,000 cows that were initially rustled. Again, there was a clash between the Fulani herdsmen and farmers on July, 2016 (Sunday Vanguard, 2016). The report had it that, not fewer than five persons were killed by the incident in Logo Local Government Area by suspected herdsmen. An eyewitness claimed that the armed herdsmen stormed the villages, singing war songs, shooting sporadically and burning houses, huts and food barns in the affected communities over clash on grazing land (Vanguard, 2016).In a related development, suspected Fulani herdsmen were reported to have killed at least 103 people in the North Central (AFP, 2015; Clara, 2018). This is one of the clashes in a long running battle with farming communities in the restive region. Between January to July, 2018, not less than 500 lives had been lost the clashes between farmers and herdsmen (Clara, 2018). The Benue state Governor, Samuel Ortom, claimed while defecting from All Progressive Congress to the Peoples Democratic Party that he cannot continue to keep his tent with a political party that has evidently failed to protect his people (Tribune, 2018).

The first Niger state experience of farmers-herdsmen conflict occurred in November 17 2016, in Kukaki community of Shiroro Local Government Area where six of the residents were killed by cattle rustlers (Vanguard, 2016). In the incident, four Fulani and two Gbagyi were said to have been killed while several others sustained different degrees of injury. The suspects, numbering about 50, according to a report, carted away about 700 cows along with other smaller animals like goats and sheep. In Plateau state, people of Riyom Local Government Area were attacked by herdsmen on March 5, 2014, killing not less than 10 people. According to Realnews (2014), more than 100 houses were also burnt when gunmen reportedly stormed Gwon, Torok, Gwawereng and Gwarim in Rim District of the Local Government Area shooting sporadically and setting houses on fire. According to a survivor, who craved anonymity, the attackers were Fulani herdsmen accompanied by some people in police uniform (Realnews, 2014). Similarly, in 2012, Senator Gyang Danton and the Majority Leader of the Plateau State House of Assembly, Mr. Gyang Fulani died in a stampede that ensued while attending the mass burial of about 50 victims of attack by Fulani herdsmen at Maseh village in Riyon LGA, Plateau State (Thisday, 2016). Till date, the North-Central geo-political zone is still witnessing regular killings of innocent people arising from farmers-herdsmen clashes (Akorede, 2018 and Adeleke, 2018).

\section{Farmers-Herdsmen Conflicts in the North-East}

In Taraba state, farmers-herdsmen crisis in Gassol appears to have been a protracted one spanning the period between 7 April, 2014 and 21 July, 2014. As reported by Gistmania Naijapals (2014), between the periods stated above, there had been series of attacks involving farmers and Fulani herdsmen resulting in several deaths and destruction of properties. 
Adamawa state also witnessed bloodletting due to farmers and herdsmen conflict over grazing right. The crisis took a religious dimension because both Christians and the Muslims houses were reportedly burnt. Premium Times (2016) reported that on Sunday, September 4, the Divisional Police Officer, DPO, in charge of Vunokilang Police Station in Girei Local Government Area of Adamawa State was reportedly killed alongside 30 other people in an attack by suspected Fulani herdsmen. The online news reported that the suspected herdsmen were said to have raided four villages: Demsare, Wunamokoh, Dikajam and Taboungo in what is believed to be a vengeance mission over an existing feud with farmers in the area. Several houses and other properties in the villages were also burnt in the attack. As at July 2018, many residents were still fleeing Adamawa and Taraba due to incessant attacks that were connected with farmers-herdsmen clashes (Goke, 2018 and Akorede, 2018).

\section{The Orgy of the Conflicts in the North-West}

On August 3, 2016, it was reported that some armed Fulani herdsmen killed at least five villagers in Jama's Local government of Kaduna state (News 24). Just like in other places, the cause of the disagreement was competition over grazing right. As reported by Vanguard (2014), another attack took place in Kaduna state on 9 March, 2014, with over 57 gunmen, suspected to be Fulani herdsmen attacked the community of Angwan Sakwai in Kaura Local Government Area and killed over 57 people (men, women and children). Houses were burnt and properties destroyed (Vanguard, 2014). The Punch (2016) reported that in another encounter, on Thursday, 13 October 2016, two police officers were ambushed and killed by suspected Fulani herdsmen along Kagoro Gidan Waya road in Kaura Local Government Area. In the attack, at a check point in the area, two other police officers were said to have sustained injuries while two escaped unhurt. The Godogodo area of Southern Kaduna in Jama'ah Local Government Area witnessed the killing of 20 persons between 15 and 16 October, 2016, by gunmen suspected to be herdsmen. Also affected in the attack were several people who sustained various degrees of injuries. Consequent upon this attack, a 24 hour curfew was imposed on the local government by the State government (Punch, 2016).On the 17 October 2016, in what seemed like a reprisal attack for the 20 people killed at Godogodo on the 15 and 16 October 2016, some suspected youths, resident in southern Kaduna were reported to have attacked, hacked and burnt 14 men, suspected to be Fulani herdsmen (Punch, 2016). According to (Goke, 2018), between July 2017 and July 2018, not less than 187 people have been killed in the North-West geo-political zone during attacks not unconnected with farmers-herdsmen clashes.

\section{South-East Encounter of the Conflicts}

In Enugu State, over 46 people were killed in Nimbo community in an attack allegedly carried out by over 500 Fulani herdsmen (Vanguard, 2016). Although, a threat was said to have been issued out by the attackers prior to the event, but nevertheless executed successfully. Security agents were reported to have responded to the threat by strategically stationing themselves in the community. But the attackers tarried until when the security agents had left the community before they carried out the retaliatory attack (Premium Times, 2016). They were also said to have fled before the security agents came back. It was reported in the Vanguard of Thursday, April 27, 2016 that over 2000 people were displaced, 40 injured and many houses and churches were destroyed as a result of the attack. Both the Senate President and the House of Representative Speaker were reported to have said, on different occasions that the farmers-herdsmen attack was threatening national unity and capable of disintegrating the country. Abia State witnessed attacked by a group of suspected Fulani herdsmen in Abam community of Arochukwu Local Government Area. Thisday (2016) reported that the incident was said to have occurred on the farms of the farmers when they were harvesting their crops (rice) on 14 November, 2016 with several people killed and others sustained various degree of injuries. As at May, 2018, killings associated with farmers-herdsmen clashes have not been fully stopped (Oyedotun, 2018).

\section{South-South Menace}

On April 19 2014, residents of 25 local government areas in Delta State grounded activities on the Benin-Asaba Expressway, protesting the killing of 23 people by the nomadic herdsmen (Thisday, 2016).

Also in June 19, 2015, Port Harcourt was thrown into pandemonium as a result of the killing of about 10 farmers by herdsmen (The nation, 2016). A lecturer and about 16 villagers were reportedly killed in Abraka on Sunday, March 26, 2017 (Punch, 2017). As at June 2018, the South-South geo-political zone is still embroiled in killings that are well established to be related to farmers-herdsmen confrontations (Akorede, 2018 and Goke, 2018). 


\section{Causes of Farmers-Herdsmen Conflicts}

Causes of farmers-herdsmen conflicts still remain majorly, due to competition over land use. This is in corroboration with the findings of Nformi et al, (2014); Abdulsalam, Dagona and Pate (2015) who noted that land related matter is the major cause of farmers-herdsmen conflicts. Merietus \& Olarewaju (2009) were even more factual in reporting the case of Benue State on the causal potential of land to conflict in the state. They posit that, land matter accounted for the highest percent (42.9\%) of conflict followed by political (32.08\%) and chieftaincy matters $(28.3 \%)$. Shettima \& Tar (2008) aver that the landlessness of the pastoralist, giving their system of pastorals, causes the competition between them and the farmers. Corroborating the preponderance of land related conflicts among other types of conflicts, Conroy (2014) added that social, political and economic dimensions of land related conflicts are also very important for proper analysis of land related conflicts. Clara (2017) blames land scarcity, competition and conflicts on colonial land partitioning between the north and the south. This is because, to him, it accentuated ethnic differences in the country and restricted the movement of group beyond some geographical areas.

Another causative factor worthy of mention is reprisal attack. This is a situation where by a group of people carry out an attack as a retaliation of an attack earlier meted on it by the other group. The question or the major concern here is whether such reprisal attacks are always in equal proportion to the one earlier meted out to them. It is also important to note that even in such situation, taking laws into one's hand is not the best but to report such issue to appropriate security agency.

Abbass (2012); Okoli \& Atelhe (2014) have tried to establish a nexus between climate change and ecological conflict. The earliest form of this work is that of Homer-Dixon where he propounded the theory of eco-violence (the conflict causal capability ensues from environmental degradation). He posits that environmental scarcity, population growth and resource access act singularly or in various mix to create scarcity of water, land and other resources. When this happens, the disadvantaged group moves to another location where they cause more pressure on the available resources in such area. Consequently, their presence is frown at and conflict ensues. On the contrary, Conroy (2014) is of the opinion that there is no concrete relationship between climate change and violent conflict. He argues that, even a search into Nigeria Watch database reveals that there is zero result for relation between climate change and conflict.

Expansion in farm production caused by encroachment of pastureland by farmers is also responsible for farmersherdsmen conflicts. According to Ismaila \& Bibi (2015), Adeleke (2018) and Akorede (2018), this is because the initial situation was that every land not cultivated is a potential pastureland but with the expansion in agriculture, it has narrowed down the available pastureland available thereby compelling the pastoralists to encroach into farmlands that were not supposed to be theirs. Where these basic needs of livelihoods of the pastoralists are not met either because of expanding land cultivation or desert encroachment, the pastoralists tend to move to some other places where they can have access to pastures (Clara, 2017). However, where they constitute more pressure to the available land resource, their presence is not always welcome. This has been found to result into conflict with the settled people of the community. Another reason for the incessant farmers - herdsmen conflicts in the northern parts of Nigeria as given by Conroy (2014) is the views of ethnic groups on land possession. He opines that, the Fulani's view land as a common resource which cannot be personalized while the sedentary communities usually see land as their exclusive preserve which no other community should encroach into.

According to Conroy (2014), migration-related issue, is the cause of conflict. He posits that this is manifest in four different ways: burden on the scarce economic and natural resources would promote native-migrant competition; migration will upset ethnic balance. It will generate tension; it could cause conflict following existing fault lines. Population explosion has been discovered, by many scholars, as one of the major causes of farmers-herdsmen conflicts in Nigeria. Several perspective of this causal phenomenon has been posited by these scholars. Nyang (2010) posits that population explosion made the farmers to cultivate more land thereby leaving little land for the pastoralist to graze on. This makes the pastoralists to move to others places where they can find more pasture for their cattle.

In a further contribution, Gefu \& Kolawole (2002); Shettima \& Tar (2008); Ofuoku (2009); Abbass (2012); Odoh \& Chigozie (2012); Adisa (2012); Nformi et al. (2014); Mwamfupe (2015) and Doyin (2017) posit that population explosion leads to more demand for food and more demand for farm produce, hence more demand for land by the farmers to be able to meet the increasing food demand. This leads to the encroachment of livestock route by the farmers in a bid to enlarge their farms for increase farm yields. 
The trampling of these supposed livestock routes, which are now other people's farms made conflict to ensue between the farmers and the herdsmen (Goke, 2018 and Akorede, 2018).

\section{Effects of Farmers-Herdsmen Conflicts on National Integration}

Farmers-herdsmen conflicts have posed a lot of implications for Nigeria's national integration. Some state Governors have been quoted as preaching for Nigeria's disintegration. For instance, the Ekiti state Governor, Mr. Ayodele Fayose has been allegedly indicted of making inciting comments capable of affecting the integration of different tribes in the country when he said farmers in his state should begin to use any means to protect themselves against militant Fulani herdsmen (The News, 2017). Many people misconstrued him to mean that he has ordered farmers to take laws to their hands. In the same vein, the Benue state Governor, Samuel Ortom has ordered Fulani herdsmen to leave Tombo-Mbalagh in Buruku Local Government Area within two days. He has ordered security agents to lead herdsmen out of the community. His defection to the opposition Peoples Democratic Party was equally linked to the perceived protection of herders by the federal government. The president in early 2018 had openly advised people of Benue state to learn to accommodate others. The president's statement further appeared like a flame to the already tensed situation in Benue state. It will take time to see if the Fulani in the northern parts of the country will not equally eject other tribes that are residing among them. The Council of State has also called on President Muhammadu Buhari to address farmers-herdsmen clashes immediately because of their threats to national unity. It is a major issue that is now threatening President Muhammed Buhari's second term.

Aside of the general effects on loss of lives, animals, farm crops, there are soil erosion, poisoning of water and displacement of farmers and pastoral problems. According to Okoli \& Atelhe, (2014); Odoh \& Chigozie (2012) who reported that 700 and 2,000 pastoralists were expelled by the local authorities in Borno and Plateau states respectively, they note that the minority question is been escalated. The Fulani tribe in most communities claim to be the minority and so claim that their rights to land (which they claim to equally own with the sedentary groups or initial settlers) access is being denied them by the sedentary groups. They also claim that, since they do not have much representation in government, government policies do not always favor them but rather alienate them from their sources of livelihood. The crisis is now snowballing into tribal and religious clashes as witnessed in Southern Kaduna, where Christians are been killed by Muslims which was occasioned by farmers-herdsmen conflict. The killing is still on and a threat on national integration. There is usually counter attack in entirely unaffected places in reaction to the loss suffered in farmers - herdsmen clashes elsewhere.

Farmers-herdsmen conflicts have the capacity to destroy source of livelihood as it is currently adding to the shortage of food and its high cost. This occurs when cattle hooves compact the soil of the farm thereby making it less productive to farmers and also, when the cattle destroy crops (Adisa \& Adekunle, 2010). In the face of prevailing disproportionate increase in food production to the growing population, farmers-herdsmen conflicts have further compounded food security because many farmers are abandoning the farm for fear of being maimed or killed. In the process, many of them move to urban centers in search of alternative means of livelihood. In so doing, they not only compound the pressure on the infrastructure in the cities but also stay unemployed. They then became susceptible tools for perpetuating violence and criminalities by the politician (Audu, 2013).

Farmers-herdsmen conflict is now said to be of co-extensiveness (cover the same area or range) with religious and culture conflicts. This is because, most farmers tend to be of the same ethnic group and mostly Christians especially in the middle belt region of Nigeria while most pastoralists are Fulani and predominantly Muslims. In an event of a conflict between these groups, they are easily perceived as ethnic or religious conflicts because of their closeness in such lines. A good example of this was 2010 Jos crisis that snowballed from leadership tussle between the Hausa residents and the settlers in the area. The aggression on the Hausa was easily transferred to the Fulani because it was perceived that they are of the same religion. This misrepresentation was partly responsible for the southern Kaduna crisis, where scores of Christians were gruesomely murdered and many churches burnt down.

The Nigerian land tenure act of 1978 has come under serious attacks by both the farmers and the Fulani. Given the incidences of conflicts, there have been agitations by different sedentary farmers and nomadic pastoralists groups to be allowed total control and access to land which have been brought under government ownership by the act. 
Farmers-herdsmen conflicts have the capability of affecting national security. In a way, farmers-herdsmen conflicts may lead to the empowerment of the marginalized group by dissidents group for ulterior motives. When farm land and cattle are either killed or stolen by rustler; it implies that the concerned parties will become jobless and unemployed.

Most of these youths then migrate to the urban settlements where they hope to secure jobs which do not exist. In most cases, the situation in the cities is even worse than the rural settlement as most youths end up not securing good jobs and cost of living becomes very high for them to bear. They then become willing tools for criminalities and atrocities.

\section{Conclusion}

Farmers-herdsmen conflicts are destructive and have far reaching consequences on national integration in Nigeria if left unchecked quickly. No doubt, such conflicts destroy resources and capable of making different tribes to be at dagger drawn with one another. It therefore calls for quick intervention from the nation's leadership. Knowledge of this fact should equally propel stakeholders, especially herdsmen and farmers to promote cultural, economic, social, religious and political understandings that are capable of uniting the various tribes in Nigeria, rather than allowing it to put them apart.

\section{Recommendations}

Given the incidents, causes and effects of farmers-herdsmen conflicts on national integration as earlier exemplified, this study recommends that the issue of land scarcity should be tackled early enough by making more arable land available to both parties. Findings have revealed that of the 81 million hectares of arable land in Nigeria, only about $41 \%$ are currently been put into use (Abbass, 2012). Therefore, more land should be cleared and leased out to both parties, without discrimination. Nomadic system of herding is archaic and outdated given the present state of development, population growth and advancement in technology. It is therefore suggested that intensive system of grazing, through ranching should be introduced so that cattle will be restricted to a particular place and foreclose chances of futures clashes. The system of animal rearing by the Nigerian herdsmen has been adjudged by many scholars as archaic. Such system can only be practiced in places with very low population density. With the exponential increase in Nigerian population and the emergence of many cities, the transhumant style of herding constitutes a great nuisance to the cities. Hence, visibility study should be carried out in consultation with state governments and indigenous land owners to ascertain the establishment of a suitable cattle ranching or grazing reserve for the herdsmen, which they should be ready to pay for.

The porous borders of Nigeria should be well manned. This is because; the porous borders allow the passage of guns from some war ravaged areas into the country. Recently, the Nigeria Customs Service intercepted about 661 new guns allegedly packed as automobile spare parts that had earlier been cleared by some connived customs personnel. This is to describe the extent some security officers can go to enrich their pockets. Some Nigeria's borders also serve as avenues for private and illegal gun dealers. This illicit trade allows a lot of guns to get into wrong hands and be used indiscriminately. Such seems to be the case of the gun-wielding herdsmen in Nigeria.

In addition, value re-orientation should be promoted so that Nigerians will come to appreciate the values that unite them more than those that divide them. Tolerance for the values of other ethnic groups should be encouraged. Efforts should be directed towards providing gainful employment for the unemployed youths who are roaming the streets of major cities in Nigeria. This will prevent them from becoming willing tools in the hands of political jobbers. Government across the various levels should provide enabling environment for the youths to pursue their aspirations. Provisions of skill and entrepreneurial trainings as well as stable electricity are basic things that should be given more priority.

Formulation and execution of government policies should not be taken to favor a group of people or a tribe against another. As it is currently, allegations of support by the federal government towards the Fulani herdsmen need to be sincerely addressed. In order to forestall further land scarcity, more grazing reserves and routes need to be created. To ease the burden that are likely to be associated with this, local communities, local governments, state governments, federal government, intergovernmental and non-governmental organizations should be engaged on how to go about this. Poverty eradication among farmers is very important so as to achieve food security, and in a way eradicate farmers-herdsmen conflicts. Farm inputs could be made available to the farmers at subsidized rates. Provision of improved seeds, with high yield capacity could also be provided to farmers so as to enable them to produce more food.

126 
Alternative Dispute Resolution (ADR) could be introduced in finding amicable resolution to farmers-herdsmen conflicts in other parts of the country instead of resorting to court settlement. This kind of conflict resolution could be enshrined into the country's national policies. For the ADR strategy to be effective, more powers have to be devolved to the local level and empower the local chiefs and traditional rulers. Local governments should collaborate in various ways to forestall occurrence of farmers-herdsmen conflicts. One of those ways they can collaborate is in the area of ensuring the registration of immigrant herdsmen in their localities.

\section{References}

Abbass, I. M. (2012). No retreat no Surrender: conflict for survival between Fulani pastoralists and farmers in northern Nigeria. European Science Journal, 8 (1), 331-346.

Abdulrahman, I., Abdulsalam, I., Dagona, Z. K., \& Pate, U. A. (2015). Understanding conflict prevention and management between Fulbe and the other ethnic groups in Adamawa State in Oshita O. O., Augustine I., Warisu A. \& Joseph H. P. (eds). Case Studies of Traditional Methods of Conflict Prevention and Resolution in Nigeria. Ibadan: John Archers Publishers. pp 157-218.

Adeleke, M. (2018). The Increasing Spate of Killings in Nigeria: Cases, Causes and the Needful, African Development, 2 (2), 32-45.

Adisa, R. S. (2012). Land use conflict between farmers and herdsmen: implications for agricultural and rural development in Nigeria. In Rashid Solagberu Adisa (Ed) Rural Development - Contemporary Issues and Practices. Europe: InTech. pp 99-118.

Adisa, R. S., \& Adekunle, O. A. (2010). Farmer - herdsmen conflicts: a factor analysis of socio-economic conflict variables among arable crop farmers in North Central Nigeria. Research Gate, 30 (1), 1-9.

AFP (2015). Suspected Fulani Herdsmen kill at least 23 in central Nigeria, May 26.

Akorede, O. P. (2018). Implications of Farmers-Herdsmen Conflicts on Nigeria's Cohesion, Journal of Multidisciplinary Studies, 7 (3), 22- 45.

Audu, S. D. (2013). Conflicts among farmers and pastoralists in northern Nigeria induced by Freshwater Scarcity. International Institute for Science, Technology and Education Journal. 3 (12), 25-32.

Bloomsfield, D., Ghai, T. \& Relly, B. (2003). The Changing Nature of Conflict and Conflict Management. In Harris P. \& Reilly B. (eds). Democracy and Deep-Rooted Conflict. Stockholm: Institute of Democracy and Electoral Assistance.

Clara, T. V. (2017). Insecurity, Loss of Lives and Policy Issues in Nigeria, African Affairs, 4 (2), 67-79.

Conroy, S. (2014). Land conflicts and lethal violence in Nigeria: patterns, mapping and evolution (2006 - 2014). IFRA - Nigeria Working Papers Series. No. 38. pp 1-38.

Doyin, T. (2017). An Empirical Investigation to Incessant Killings in Nigeria, Journal of Philosophy, 5. 67-82.

Faleti, S. A. (2015) "Theories of Social Conflict". In Shadrack Gaya Best (ed). Introduction to Peace and Conflict Studies in West Africa. Ibadan: Spectrum Books Limited. pp: 35-60.

Galtung, J. (1996). Peace by peaceful means. London: Sage Publishers.

Gefu, O. J., \& Kolawole, A. (2002). Conflict in common property resource use: experiences from an irrigation project. A Paper presented during the $9^{\text {th }}$ biennial conference of the International Association for the Study of Common Property.

Goke, S. (2018). The Genesis of Farmers-Herdsmen Clashes in Nigeria, Journal of Social Sciences, 4 (2), 34-48.

IRIN, 2009 - "Nigeria: Curbing farmer-nomad clashes and protecting livestock routes" Integrated Regional Information Networks (IRIN) http://www.preventionweb.net/english/professional/news/v.phd

Maltosa, K. (1999). Conflict management: Lesotho political crisis after the 1998 elections in Lesotho. Social Science Review. 5 (1), 22 - 34.

Marietu S. T., \& Olarewaju, O. I. (2009). Resource conflict among farmers and Fulani herdsmen: implications for resource sustainability. African Journal of Political Science and International Relation. 3 (9), 360-364. Retrieved from http://www.academicjournals.org/ajsir.January 232017.

Moritz, M. (2003). The demise of the nomadic contract: arrangements and rangelands under pressure in the far north of Cameroon. Nomadic Peoples. 6 (1), 127-146.

Ismaila, A. B., \& Bibi, U. M. (2015). An assessment of farmer - pastoralist conflict in Nigeria using GIS. International Journal of Engineering Science Invention. 4 (7), 23-33. 
Mwamfupe, D. (2015). Persistence of farmer - herder conflicts in Tanzania. International Journal of Scientific and Research Publications, 5 (2) 1- 8.

New Nigerian, (2010) “30 injured in Adamawa cattle rearers invasion”, Monday February 1st 2009.

News 24 (2016, August 3). Five killed in clash over land in Nigeria.

Nformi, M. I., et al, (2014). Effects of farmer - grazer conflicts on rural development: a Socio-economic analysis. Scholarly Journal of Agricultural Science. 4 (3), 113-120. Retrieved on 15 January, 2017 from http://www.scholarly-journals.com/SJAS

Nyang, A. (2010). Climate - related conflicts in West Africa. Population, Health, Environment, and Conflict Report from Africa. 12, 36-43.

Nzeh, E. (2015). The effects of migration by nomadic farmers in the livelihoods of rural crop farmers in Enugu state, Nigeria. Global Journal of Science Frontier Research. 15 (3), 45 - 56.

Odoh, S. I., \& Chigozie, C. F. (2012). Climate change and conflict in Nigeria: a theoretical and empirical examination of the worsening incidence of conflict between Fulani herdsmen and farmers in northern Nigeria. Arabian Journal of Business and Management Review. 2 (1), 110-124.

Ofem, O. O., \& Bassey, I. (2014). Livelihood and conflict dimension among crop farmers and Fulani herdsmen in Yakurr region of Cross River state. Mediterranean Journal of Social Sciences. 5 (8), 512-519.

Ofuoke, A. (2009). The role of community development committees in farmer - herder conflicts in central agricultural zone of Delta State, Nigeria. Journal of Alternative Perspectives in the Social Sciences. 1 (3), 921-937.

Ojo, E. (2009). Federalism and the search for national integration in Nigeria. African Journal of Political Science and International Relations, 3 (9), 384-395.

Okoli, A. C., \& Atelhe, G. A. (2014). Nomads against natives: a political ecology of herder/farmer conflicts in Nasarawa State, Nigeria. American International Journal of Contemporary Research. 4 (2) 76-88.

Omawumi, E. (2016). History of Fulani herdsmen and farmers clashes in Nigeria, The News, March 23.

Oyedotun, W. (2017). New Dimensions to the Killings of Farmers in Nigeria, Tribune Editorial, $23^{\text {rd } J u l y . ~}$

Oyeyipo, S., James, S. \& Sanda, J. (2015). The new terror threat, Retrieved on 16 January 2017 from www.punchng.com

Punch (2016). Poll: what is the solution to the Fulani herdsmen/farmers conflict? Retrieved on January 19, 2017 from http://www.punchng.com

Punch (2017). University Don Others killed by herdsmen in Abraka, Editorial.

Realnews, (2014). April 7). The menace of Fulani herdsmen. April 7

Shettima, A. G., \& Tar, U. A. (2008) Farmer - pastoralist conflict in West Africa: exploring the causes and consequences. Information, Society and Justice. 1.(2), 163-184.

Sunday Vanguard, (2016). 81 feared dead as armed Fulani herdsmen go shooting spree. Retrieved on 20 Januaty 2017 from. www.vanguardngr.com

The News (2017). Governor Ortom orders herdsmen to leave Benue Community, Editorial, March 29.

The nation (2016). Agatu killing and road to apocalypse. Retrieved 22 January from http://www.nationonlineng.com

Thisday (2016). The new terror threat. Retrieved on 23 January, 2017 from http://www.thisdaylive.com

Vanguard (2016). Fulani herdsmen attacks threaten Nigeria's existence - Retrieved on 20 January from www.vanguardngr.com

Vanguard (2016). Cattle rustlers kill 6 in Niger. Retrieved on 22 January, 2017 from www.vanguardngr.com 